\title{
ANALISIS BIAYA PERBAIKAN ULIR DI PT. ALLOY MAS OILFIELD SERVICES DENGAN METODE ACTIVITY BASED COSTING
}

\author{
Widi Andriyanto, Aifrid Agustina, Muhammad Kholil \\ Program Studi Teknik Industri \\ Universitas Mercu Buana Jakarta \\ grg0503@gmail.com,m.kholil2009@gmail.com
}

\begin{abstract}
Abstrak
Sebagai pemula di bidang minyak dan gas PT. Alloy Mas Oilfield Services ingin bersaing dengan perusahaan lain yang telah lama malang melintang di bidang minyak dan gas terutama di sektor perbaikan ulir untk Spec 7-1. Dengan menerapkan perhitungan yang jeli dan riil terhadap aktivitasaktivitas yang memerlukan biaya, PT. Alloy Mas Oilfiled Services mencoba mendapatkan biaya aktivitasnya. Menggunakan metoda Activity Based Costing untuk menghitung biaya aktivitas dengan mengalokasikan biaya secara tepat akan memudahkan dalam penentuan harga perbaikan ulir tersebut. Dengan mengidentifikasi aktivitas-aktivitas yang ada dalam proses perbaikan ulir, maka akan mendapat besar biaya yang valid untuk perhitungan biaya aktivitas.Dari perhitungan dengan metoda Activity Based Costing,didapat rincian biaya untuk perbaikan ulir Spec 7-1 yang antara lain untuk perbaikan koneksi NC 38 Pin Rp 893,654, koneksi NC 38 Box Rp 885,006, koneksi NC 50 Pin Rp 861,527, koneksi NC 50 Box Rp 883,983, koneksi 6 5/8 REG Pin Rp 849,489, koneksi 6 5/8 REG Box Rp 957,082. Dari biaya aktivitas ini bisa digunakan penentuan harga perbaikan ulir saat adanya tender. Sehingga harga yang diberikan akan lebih kompetitif dengan para pesaing.
\end{abstract}

Kata kunci : Perbaikan Ulir, Metoda Activity Based Costing.

\section{PENDAHULUAN}

Indonesia merupakan negara penyumbang wilayah pengeboran minyak dan gas bumi.Dengan adanya aktivitas pengeboran ini, sudah tentu penggunaan peralatan pengeboran tambang minyak bumi ini semakin banyak dan perlu adanya perbaikan sarana dan prasarananya.Sebagian besar peralatan pengeboran minyak ini berukuran panjang dan besar.Pada setiap peralatan, khususnya pipa pengeboran disambungkan dengan sistem ulir. Ulir inilah yang nantinya akan diperbaiki setelah peralatan pengeboran ini mengalami bongkar pasang setelah melakukan aktivitas pengeboran. Sebelum dinyatakan ulir ini akan diperbaiki, sebelumnya dicek oleh seorang QC inspektor yang berstandar pada baku inspeksi tentang alat pertambangan ini. Dengan adanya kebutuhan perbaikan dan perawatan alat pengeboran minyak ini, PT. Alloy Mas Oilfield Services memulai usahanya dengan memanfaatkan peluang tersebut.PT.Alloy Mas Oilfield Services ini berdiri baru sejak tahun 2008. Mengingat usianya yang masih muda dan sebagai pemain baru dalam industri perminyakan bidang perbaikan dan manufaktur menghadapi persaingan yang sangat ketat. Sebagai penyedia jasa perbaikan peralatan pertambangan minyak PT. Alloy Mas Oilfield Services dituntut untuk bisa menghadapi tantangan tersebut. Tidak lupa juga, sebagian pengadaan perbaikan peralatan pertambangan minyak ini dilakukan dengan proses tender, sehingga akan menimbulkan persaingan harga yang lebih kompetitif, peralatan/fasilitas yang dimiliki juga harus mumpuni, ditunjang dengan sumber daya manusia yang punya kinerja dan daya saing tinggi untuk memenangkan persaingan tersebut. Dengan hal ini, biaya jasa perbaikan peralatan ini harus bisa serendah-rendahnya tanpa mengurangi keuntungan yang diharapkan oleh perusahaan.

PT. Alloy Mas Oilfield Services menyadari sepenuhnya hal tersebut, karena merasa dirinya pemula dibidang ini sudah pasti adanya pesaing dalam usaha ini. Untuk itu PT. Alloy Mas Oilfield Services mencari cara untuk bisa menangani masalah tersebut dengan melakukan penelitian atau mendesain ulang konsep dengan menganalisis biaya perbaikan peralatan tambang ini dengan menggunakan metoda Activity Based Costing. Dengan menggunakan metoda ini diharapkan dalam menentukan harga jasa perbaikan ulir peralatan 
tambang perminyakan lebih akurat dan bersaing tanpa mengorbankan operasionalnya. Berdasarkan latar belakang tersebut maka peneliti akan melakukan penelitian mengenai analisa biaya perbaikan ulir di PT. Alloy Mas Oilfield Services dengan metoda Activity Based Costing.

\section{LANDASAN TEORI}

Menurut Supriyono(2000), biaya adalah harga perolehan yang dikorbankan atau digunakan dalam rangka memperoleh penghasilan atau revenue yang akan dipakai sebagai pengurang penghasilan.Menurut Simamora (2002), biaya adalah kas atau nilai setara kas yang dikorbankan untuk barang atau jasa yang diharapkan memberi manfaat pada saat ini atau di masa mendatang bagi organisasi.Menurut Mulyadi (2001), biaya adalah pengorbanan sumber ekonomis yang diukur dalam satuan uang, yang telah terjadi, sedang terjadi atau yang kemungkinan akan terjadi untuk tujuan tertentu. Menurut Bustami (2007), biaya atau cost adalah pengorbanan sumber ekonomis yang diukur dalam satuan uang yang telah terjadi atau kemungkinan akan terjadi untuk mencapai tujuan tertentu. Biaya ini belum habis masa pakainya, dan digolongkan sebagai aktiva yang dimasukkan dalam neraca.

Activity Based Costing merupakan metode yang menerapkan konsep-konsep akuntansi aktivitas untuk menghasilkan perhitungan harga pokok produk yang lebih akurat. Namun dari perspektif manajerial, sistem $\mathrm{ABC}$ menawarkan lebih dari sekedar informasi biaya produk yang akurat akan tetapi juga menyediakan informasi tentang biaya dan kinerja dari aktivitas dan sumber daya serta dapat menelusuri biaya-biaya secara akurat ke objek biaya selain produk, misalnya pelanggan dan saluran distribusi.

Pengertian akuntansi aktivitas menurut Widjaja (1992) adalah: "Bahwa ABC Sistem tidak hanya memberikan kalkulasi biaya produk yang lebih akurat, tetapi juga memberikan kalkulasi apa yang menimbulkan biaya dan bagaimana mengelolanya, sehingga ABC System juga dikenal sebagai sistem manajemen yang pertama." Sedangkan menurut Hansen dan Mowen (2001), biaya pemasaran adalah biaya-biaya yang diperlukan untuk memasarkan produk atau jasa, meliputi biaya gaji dan komisi tenaga jual, biaya iklan, biaya pergudangan dan biaya pelayanan pelanggan.

\section{METODOLOGI PENELITIAN}

Dalam penelitian ini mengunakan dua jenis metoda penelitian, yaitu :

\section{Studi Pustaka}

Semua bahan yang digunakan dalam penelitian ini diperoleh dari hasil studi berbagai buku, e-book, dan atau jurnal.

2. Studi Lapangan

Data yang digunakan dalam penelitian ini merupakan data yang diambil langsung peneliti di PT. Alloy Mas Oilfield Services.

\section{HASIL DAN PEMBAHASAN}

Dalam pemberian harga jasa perbaikan ulir di PT. Alloy Mas Oilfield Services dilakukan untuk setiap jenis koneksi yang dihasilkan.Sehingga biaya-biaya yang diperhitungkan merupakan biaya-biaya yang terjadi pada perbaikan jenis ulir tersebut maupun hasil dari alokasi biaya umum dari produk. Besarnya alokasi biaya tersebut didasarkan pada masing-masing jenis koneksi yang dihasilkan dari perbaikan ulir pada barang Drill Pipe. Dimana jenis koneksi ulir yang akan dihitung dalam proses perbaikan ulir di PT. Alloy Mas Oilfield Services antara lain sebagai berikut:

1. Koneksi NC 38 PIN

2. Koneksi NC 38 BOX

3. Koneksi NC 50 PIN

4. Koneksi NC 50 BOX

5. Koneksi 6 5/8 REG PIN 
6. Koneksi 6 5/8 REG BOX

Penghitungan biaya aktivitas dengan metode tradisional untuk masing-masing koneksi adalah:

Tabel 1. Perhitungan Biaya Koneksi NC 38 Pin dengan Metode Tradisional

\begin{tabular}{|c|c|c|c|}
\hline Jenis Biaya & Total Biaya & Jumlah Produksi & Biaya per Unit \\
\hline Biaya Bahan Baku & Rp. $75,826,180$ & 338 & Rp. 224,338 \\
\hline $\begin{array}{l}\text { Biaya Tenaga Kerja } \\
\text { Langsung }\end{array}$ & Rp. $46,717,878$ & 338 & Rp. 138,219 \\
\hline Biaya Overhead & Rp. $213,524,259$ & 338 & Rp. 631,729 \\
\hline
\end{tabular}

Tabel 2. Perhitungan Biaya Koneksi NC 38 Box dengan Metode Tradisional

\begin{tabular}{|c|c|c|c|}
\hline Jenis Biaya & Total Biaya & Jumlah Produksi & Biaya per Unit \\
\hline Biaya Bahan Baku & Rp. 79,639,923 & 355 & Rp. 224,338 \\
\hline $\begin{array}{l}\text { Biaya Tenaga Kerja } \\
\text { Langsung }\end{array}$ & Rp. $49,067,594$ & 355 & Rp. 138,219 \\
\hline Biaya Overhead & Rp. $223,976,495$ & 355 & Rp. 630,920 \\
\hline
\end{tabular}

Tabel 3. Perhitungan Biaya Koneksi NC 50 Pin dengan Metode Tradisional

\begin{tabular}{|l|c|c|c|}
\hline \multicolumn{1}{|c|}{ Jenis Biaya } & Total Biaya & Jumlah Produksi & Biaya per Unit \\
\hline Biaya Bahan Baku & Rp. $192,930,518$ & 860 & Rp. 224,338 \\
\hline Biaya Tenaga Kerja & Rp. $118,867,974$ & 860 & Rp. 138,219 \\
Langsung & Rp. $542,769,707$ & 860 & Rp. 631,128 \\
\hline Biaya Overhead & \multicolumn{2}{|l}{ Rp. 993,684} \\
\cline { 5 - 5 }
\end{tabular}

Tabel 4. Perhitungan Biaya Koneksi NC 50 Box dengan Metode Tradisional

\begin{tabular}{|c|c|c|c|}
\hline Jenis Biaya & Total Biaya & Jumlah Produksi & Biaya per Unit \\
\hline Biaya Bahan Baku & Rp. $167,580,345$ & 747 & Rp. 224,338 \\
\hline $\begin{array}{l}\text { Biaya Tenaga Kerja } \\
\text { Langsung }\end{array}$ & Rp. $103,249,275$ & 747 & Rp. 138,219 \\
\hline Biaya Overhead & Rp. 471,843,817 & 747 & Rp. 631,652 \\
\hline & & & Rp. 994,208 \\
\hline
\end{tabular}

Tabel 5. Perhitungan Biaya Koneksi 65/8 REG Pin dengan Metode Tradisional

\begin{tabular}{|l|c|c|c|}
\hline \multicolumn{1}{|c|}{ Jenis Biaya } & Total Biaya & Jumlah Produksi & Biaya per Unit \\
\hline Biaya Bahan Baku & Rp. $28,490,902$ & 127 & Rp. 224,338 \\
\hline $\begin{array}{l}\text { Biaya Tenaga Kerja } \\
\text { Langsung }\end{array}$ & Rp. $17,553,759$ & 127 & Rp. 138,219 \\
\hline Biaya Overhead & Rp. $79,884,950$ & 127 & Rp. 629,015 \\
& & Rp. 991,572 \\
\hline
\end{tabular}


Tabel6. Perhitungan Biaya Koneksi 6 5/8 REG Box dengan Metode Tradisional

\begin{tabular}{|l|l|c|c|}
\hline \multicolumn{1}{|c|}{ Jenis Biaya } & Total Biaya & Jumlah Produksi & Biaya per Unit \\
\hline Biaya Bahan Baku & Rp. $15,927,985$ & 71 & Rp. 224,338 \\
\hline $\begin{array}{l}\text { Biaya Tenaga Kerja } \\
\text { Langsung }\end{array}$ & Rp. $9,813,519$ & 71 & Rp. 138,219 \\
\hline Biaya Overhead & Rp. $44,795,299$ & 71 & Rp. 630,920 \\
\end{tabular}

Langkah-langkah yang dilakukan untuk mengetahui keakuratan biaya pada kegiatan perbaikan ulir di PT. Alloy Mas Oilfield Services sebagai berikut:

1. Mengidentifikasi aktivitas-aktivitas

Dalam mengidentifikasi aktitivitas-aktivitas yang terjadi, penulis mengamati secara langsung dari barang datang dari customer hingga barang tersebut siap dikirim kembali ke customer.

2. Membebankan Biaya masing-masing Aktivitas

Setelah tiap aktivitas diidentifikasi, selanjutnya menghitung biaya-biaya dan sumber daya yang timbul dari tiap aktivitas tersebut. Sebisa mungkin pembebanan biaya seaktual mungkin untuk mendapatkan perhitungan yang valid dan teruji.

a. Aktivitas penerimaan barang

Biaya yang timbul dari aktivitas ini meliputi Unloading barang dari truk dilakukan dengan 2 orang operator forklift dengan gaji masing-masing Rp 2,445,000 dan Rp $3,400,000$ per bulan sehingga jumlah total dalam kurun 6 bulan Rp 35,070,000.

b. Aktivitas pengecekan barang

Pengecekan barang dilakukan oleh departemen QC dengan 3 orang pekerja masingmasing dengan gaji Rp 2,600,000 sebanyak 2 orang dan Rp 2,700,000 sehingga total gaji dalam periode yang diteliti penulis sepanjang 6 bulan Rp 47,400,000.

c. Aktivitas penguliran

Penguliran ini dilakukan oleh 8 orang operator bubut dengan gaji Rp 5,400,000 sebanyak 2 orang, yang lainnya ada yang Rp 4,000,000 , Rp 3,800,000 , Rp 3,700,000, Rp 3,350,000, Rp 3,050,000, dan Rp 2,800,000. Sehingga total untuk 6 bulan sebanyak Rp 189,000,000.

d. Aktivitas Cold Roll

Aktivitas Cold Roll ini dilakukan oleh helper operator bubut yang bergaji standar UMR yaitu sekitar Rp 2,450,000 sebanyak 4 orang.Total gaji untuk mereka selama 6 bulan sebanyak Rp 58,800,000.

e. Aktivitas Pencelupan larutan Mangan

Aktivitas pencelupan larutan mangan dilakukan oleh satu orang yang memiliki gaji Rp 2,500,000. Sehingga untuk periode 6 bulan totalnya Rp 15,000,000.

f. Aktivitas pengiriman Aktivitas ini dilakukan oleh bagian Shipping dan Receiving dimana bagian ini juga dilakukan oleh orang yang sama saat aktivitas penerimaan barang sehingga gajinya sudah termasuk melakukan aktivitas ini.

3. Menentukan pemicu biaya

Selanjutnya setelah tahap pembebanan aktivitas adalah tahap menentukan pemicu biaya dari masing-masing aktivitas.

a. Aktivitas penerimaan barang

Hal yang memicu biaya pada aktivitas penerimaan barang ialah jumlah barang Drill Pipe yang masuk ke PT. Alloy Mas Oilfield Services. Semakin meningkat jumlah barang yang masuk maka semakin meningkat pula biayanya.

Tarif per unit cost driver $=\mathrm{Rp} 56,708,167 / 1546=\mathrm{Rp} 36,680.57$ 
b. Aktivitas pengecekan barang

Pemicu biaya aktivitas ini adalah jumlah barang masuk yang hendak diperbaiki ulirnya di PT. Alloy Mas Oilfield Services. Jumlah barang ini yang menentukan besarnya biaya yang tertanggung.

Tarif per unit cost driver $=\operatorname{Rp} 92,611,584 / 1546=\mathrm{Rp} 59,904$

c. Aktivitas penguliran

Pada aktivitas penguliran yang menjadi pemicu biaya adalah jumlah koneksi.

Semakin banyak koneksi yang diperbaiki semakin meningkat juga biayanya.

Tarif per unit cost driver $=\mathrm{Rp} 664,904,760 / 2498=\mathrm{Rp} 266,174.84$

d. Aktivitas Cold Roll

Sama dengan aktivitas penguliran pemicu biaya aktivitas ini juga jumlah koneksi.

Tarif per unit cost driver $=\mathrm{Rp} 62,736,768 / 2498=\mathrm{Rp} 25,114.80$

e. Aktivitas pencelupan larutan Mangan

Pemicu biayanya jumlah koneksi yang diperbaiki, semakin banyak semakin meningkat biaya.

Tarif per unit cost driver $=\mathrm{Rp} 28,704,575 / 2498=\mathrm{Rp} 11,491.02$

Untuk biaya overhead yang dibebankan sekitar $65 \%$ saja. Pemicu biaya dari overhead ini adalah jumlah koneksi yang diperbaiki.

Tarif per unit cost driver $=(\operatorname{Rp} 1,576,794,527 \times 65 \%) / 2498=R p 410,295$

Dari hasil pengumpulan dan pengolahan data, dapat terlihat hasil perhitungan biaya dengan metode tradisional dan metoda Activity Based Costing memiliki perbedaan yang signifikan. Rangkuman tersebut dapat dilihat pada tabel di bawah ini :

Tabel 7.Perbandingan perhitungan biaya dengan metode tradisional dan metode $\mathrm{ABC}$

\begin{tabular}{|c|c|c|c|c|c|c|}
\hline & $\begin{array}{c}\text { NC } 38 \\
\text { Pin }\end{array}$ & $\begin{array}{c}\text { NC } 38 \\
\text { Box }\end{array}$ & $\begin{array}{c}\text { NC } 50 \\
\text { Pin }\end{array}$ & $\begin{array}{c}\text { NC } 50 \\
\text { Box }\end{array}$ & $\begin{array}{c}65 / 8 \text { Reg } \\
\text { Pin }\end{array}$ & $\begin{array}{c}65 / 8 \mathrm{Reg} \\
\text { Box }\end{array}$ \\
\hline $\begin{array}{l}\text { Sistem } \\
\text { Tradisional }\end{array}$ & $\begin{array}{c}\mathrm{Rp} \\
994,285\end{array}$ & $\begin{array}{c}\mathrm{Rp} \\
993,476\end{array}$ & $\begin{array}{c}\mathrm{Rp} \\
993,684 \\
\end{array}$ & $\begin{array}{c}\text { Rp } \\
994,208\end{array}$ & $\begin{array}{c}\mathrm{Rp} \\
991,572 \\
\end{array}$ & $\begin{array}{l}\mathrm{Rp} \\
993,476\end{array}$ \\
\hline $\begin{array}{l}\text { Sistem } \\
\text { ABC }\end{array}$ & $\begin{array}{c}\mathrm{Rp} \\
893,654\end{array}$ & $\begin{array}{c}\mathrm{Rp} \\
885,006\end{array}$ & $\underset{861,527}{\mathrm{Rp}}$ & $\begin{array}{c}\mathrm{Rp} \\
883,983\end{array}$ & $\begin{array}{c}\mathrm{Rp} \\
849,489\end{array}$ & $\begin{array}{l}\mathrm{Rp} \\
957,082\end{array}$ \\
\hline Selisih & $\begin{array}{c}\mathrm{Rp} \\
100,631\end{array}$ & $\begin{array}{c}\mathrm{Rp} \\
108,470\end{array}$ & $\begin{array}{c}\mathrm{Rp} \\
132,157\end{array}$ & $\begin{array}{c}\mathrm{Rp} \\
110,225\end{array}$ & $\begin{array}{c}\mathrm{Rp} \\
142,083\end{array}$ & Rp 36,394 \\
\hline $\begin{array}{l}\text { Presentase } \\
(\%)\end{array}$ & (10.12) & (10.92) & (13.30) & (11.09) & (14.33) & (3.66) \\
\hline
\end{tabular}

Dari tabel 7 di atas diketahui bahwa dengan menggunakan metoda Activity Based Costing lebih sedikit biaya aktivitas yang dibebankan. Adanya perbedaan ini disebabkan karena pada metode tradisional pembebanan biaya pada satu cost driver saja, sedangkan metoda Activity Based Costing mengalokasikan biaya ke masing-masing aktivitas berdasar konsumsi aktivitas.

Sistem Activity Based Costing menghasilkan perhitungan biaya produksi yang lebih akurat dibandingkan sistem tradisional (konvensional). Tingkat akurasi ini sangat penting bagi perusahaan dalam menetapkan keputusan yang berkaitan dengan manajemen perusahaan, misalnya dalam penetapan harga jual. Sehingga dapat digunakan untuk menghadapi persaingan yang semakin kompetitif.

Keberhasilan sistem Activity Based Costing dalam memperbaiki kelemahan sistem tradisional (konvensional). Apabila PT. Alloy Mas Oilfield Services ingin mencoba alternatif penerapan sistem Activity Based Costing, maka ada tiga petunjuk yang perlu diperhatikan, yaitu: 
1. Usahakan sistem sesederhana mungkin dan mudah dimengerti. Sistem tersebut harus merefleksi bagaimana perusahaan menyebabkan biaya terjadi.

2. Setiap perusahaan adalah berbeda. Sifat biaya secara luas berbeda dari suatu perusahaan keperusahaan lain. Hal ini berguna dalam pemilihan cost driver.

3. Memahami tujuan apa yang manajemen inginkan adalah sistem biaya mendukungnya. Manajemen perusahaan mempunyai banyak keputusan yang dibuat sehubungan dengan desain sistem.

\section{KESIMPULAN DAN SARAN}

Berdasarkan hasil perhitungan harga perbaikan ulir menggunakan metoda Activity Based Costing dapat ditarik kesimpulan sebagai berikut:

1. Biaya perbaikan koneksi NC 38 Pin Rp 893,654, koneksi NC 38 Box Rp 885,006, koneksi NC 50 Pin Rp 861,527, koneksi NC 50 Box Rp 883,983, koneksi 6 5/8 REG Pin Rp 849,489, koneksi 6 5/8 REG Box Rp 957,082.

2. Penghitungan biaya dengan metoda Activity Based Costing lebih akurat. Ini terjadi karena perhitungan biaya yang dilakukan sudah bisa mengalokasikan biaya ke masingmasing aktivitas secara tepat.

3. Dengan penghitungan yang lebih akurat mendorong managemen untuk bisa lebih menekan harga jual untuk bersaing dengan para kompetitor.

PT. Alloy Mas Oilfield Services seharusnya mulai menggunakan perhitungan biaya dengan metoda Activity Based Costing dalam menyusun harga perbaikan ulir.Karena perhitungan dengan Activity Based Costing memberikan informasi yang akurat untuk biaya perbaikan ulir. Penulis menyarankan agar managemen mengadakan penelitian lebih lanjut tentang Activity Based Costing dalam melakukan proses produksi sehingga bisa memberikan harga perbaikan ulir yang lebih kompetitif. Ini ditujukan untuk menambah daya saing PT. Alloy Mas Oilfield Services dengan para pesaingnya.

\section{DAFTAR PUSTAKA}

[1] Bustami, B, 2007, Akuntansi Biaya, Graha Ilmu, Jakarta.

[2] Hansen dan Mowen, 2001,Manajemen Biaya, Edisi bahasa Indonesia, Buku Dua, Edisi Pertama, Salemba Empat, Jakarta.

[3] Mulyadi, 2005, Akuntansi Biaya,edisi ke-6, STIE YKPN, Yogyakarta.

[4] Simamora, H., 2002, Akuntansi Manajemen, Salemba Empat, Jakarta.

[5] Supriyono, 2000, Akuntansi Biaya, Buku 1, edisi dua, BPFE, Yogyakarta.

[6] Widjaja, A., 1992, Pengantar Activity Based Costing, Rineka Cipta, Jakarta. 